\title{
In memory of Professor Arnold L. Demain
}

\author{
Julian E. Davies ${ }^{1}$
}

Published online: 28 May 2020

(c) The Author(s), under exclusive licence to the Japan Antibiotics Research Association 2020

Professor Arnold Lester Demain passed away on Friday, April 3, 2020 at age 92, just shy of his 93rd birthday, from complications due to COVID-19.

He was a wonderful man, a kind person, hard worker, and loving father, with a great sense of humor. A research microbiologist and university professor, he mentored several generations of scientists and doctors into his 90 s and was beloved by all of them. He was born on April 26, 1927, in Williamsburg, Brooklyn, and raised in Brooklyn and the Bronx, NY, during the great depression. Arny graduated high school at 16 and attended Michigan State College (now University), earning Bachelor's and Master's degrees. At 17, during his college years, he enlisted in the Navy toward the end of the Second World War, and served in the Hospital Corps, returning to Michigan State after the war was over.

After receiving his Master's degree, he attended the University of California for his PhD. Although he began his doctoral degree at the Berkeley campus, his Department relocated 2 years later to the UC campus at Davis when that campus opened and he remained there until he graduated. From there, he began a 16-year career at Merck Sharp \& Dohme Research Laboratories, first in Pennsylvania and then in New Jersey, working on penicillin and other natural product research. By 1969, he was Head of the Fermentation Microbiology Department at Merck, when he was recruited by the Massachusetts Institute of Technology (MIT) to become a full professor in the Nutrition and Food Science Department, which later merged into the Biology Department. He stayed at MIT until he took "early retirement" at age 75, and Arny and Jody moved to Madison, NJ, in 2000 to be near their daughter and grandchildren.

Back in NJ, Arny was a member of the R.I.S.E. Institute at Drew University, a research laboratory and teaching

Julian E. Davies

jed@mail.ubc.ca

1 Professor Emeritus University of British Columbia, Vancouver, Canada institution for retired scientists. He continued his work at Drew University, performing research and mentoring students, until May 2019, when he fully retired at age 92. Over the years, he taught and welcomed to his laboratory hundreds of students from around the world at all levels, from high school students, to undergrads, and graduate students, as well as postdocs. His students were all members of "Arny's Army and Friends," an informal group that developed over the years beginning at MIT in the 1970's. Since his retirement from MIT, his students have held "Arny's Army and Friends" Symposia in his honor, every 3 years, around the world.

He had a great life, traveling all over the world from the 1960s through a few years ago, attending scientific meetings, lecturing, and consulting in the pharmaceutical industry, where he consulted for many pharmaceutical companies around the world. He had a "second career" as an expert witness in patent cases. He has written or edited many books and countless scientific articles, published in peer-reviewed journals. He was involved in the creation of the biotech industry in the early 1970s, serving as the founding consultant to the first-ever biotech company, Cetus Corporation, which was located in Berkeley, California. He is the recipient of many honorary degrees and awards, including one from the King of Spain and one from the Emperor of Japan. He was selected to become a member of the National Academy of Sciences in 2000. In 2019, Drew University established an endowed scholarship in his name to commemorate his 90th birthday.

He is survived by his wife of 68 years, Joanna (Jody) Demain, daughter, Pamela Demain, his son Jeffrey Demain and Jeff's wife Lauren Brener, his grandchildren and their spouses, Megan and Michael Neilson, and Andrew and Hillary McCloskey, as well as his great-grandchildren Grant Carter Neilson and Parker Reid Neilson.

Arny's interests outside of science included a great love of baseball, stemming from his early years in the Bronx, where he was a Yankees fan. When he relocated to Massachusetts to teach at MIT, he became a devout Red Sox fan, and remained so for the rest of his years. He was also a 
big music fan, especially of his idols of his youth-Louis Armstrong, Benny Goodman, and Ella Fitzgerald-and later Frank Sinatra. He instilled a love of music, dance, and singing in his children. With Jody, he was a great dancer; they were always the first couple on the dance floor.

He will be missed deeply by his family, his colleagues, and his students, but they will all take solace in remembering what a happy and full life he enjoyed.
A memorial service in Arny's honor for family, friends, colleagues, and former students, will be held when it is safe to do so. Donations in his memory can be made to the Alzheimer's Foundation of America at https://alzfdn.org/.

Julian E. Davies, Ph.D.

Professor Emeritus

University of British Columbia 